\title{
Essential Oil Yield and Composition of Lamiaceae Species Growing in Southern Brazil
}

\author{
Fabiana Agostini ${ }^{1 *}$, Ana Cristina Atti dos Santos ${ }^{1,2}$, Marcelo Rossato ${ }^{1,3}$, Márcia Regina \\ Pansera $^{1}$, Paula Luciana dos Santos ${ }^{1}$, Luciana Atti Serafini ${ }^{1,2}$, Rosângela Molon ${ }^{4}$ and \\ Patrick Moyna ${ }^{5}$ \\ ${ }^{I}$ Instituto de Biotecnologia; Universidade de Caxias do Sul; Caxias do Sul - RS - Brasil; ${ }^{2}$ Departamento de Física e \\ Química; Universidade de Caxias do Sul; Caxias do Sul - RS - Brasil. ${ }^{3}$ Departamento de Ciências Exatas e da \\ Natureza; Universidade de Caxias do Sul; Caxias do Sul - RS - Brasil. ${ }^{4}$ Herbário; Universidade de Caxias do Sul; \\ Rua Francisco Getúlio Vargas, 1130; 95001-970; Caxias do Sul - RS - Brasil. ${ }^{5}$ Cátedra de Ciencia y Tecnologia de \\ Alimentos; Facultad de Química; Universidad de La Republica; UR 11800; Montevideo - Uruguay
}

\begin{abstract}
The Lamiaceae family has been described to be rich in essential oil. The aim of the present work was to identify the native species of Rio Grande do Sul with potential use as the aromatic plants. Seven species of the family were collected in the different localities of the state. The essential oils were obtained by 1 h hydrodistillation in a Clevenger apparatus. The constituents were identified by comparing their GC Kovats retention indices (RI), determined with reference to a homologous series of n-alkanes and by comparing their mass spectral fragmentation patterns with literature data. Cunila incisa and Mentha aquatica resulted in the higher esssential oil yields (1.94\% $v / w$ and $0.93 \% v / w$, respectively. The composition of $\mathrm{M}$. aquatica was $80 \%$ methone, with almost $14 \%$ pulegone. C. microcephala had 53\% menthofuran and C. incisa nearly $45 \%$ of 1.8 -cineol and $18 \%$-terpineol.
\end{abstract}

Key words: Lamiaceae species, essential oil composition, Southern Brazil, hydrodistillation

\section{INTRODUCTION}

Lamiaceae is a relatively common botanical family, members of which are found in the temperate regions worldwide (Cantino, 1992). It includes approximately 220 genera and about 3,500 to 4,000 species (Almeida and Albuquerque, 2002). Most species are herbaceous, arbustive or subarbustive (Craveiro et al., 1981), annual or perennial (Watson and Dallwitz, 1991), simple or composite with opposed or crossed leaves (Craveiro et al., 1981), which can be sessile or petiolate (Watson and Dallwitz, 1991). The lowers are bilabiate, of different sizes, solitary or united in dense terminal or axial inflorescences (Craveiro et al., 1981; Watson and Dallwitz, 1991) which are usually highly aromatic (Lawrence, 1992).

Many of the species are used as the ornamentals (Cantino, 1992; Watson and Dallwitz, 1991) and can potentially be used as the medicinal or aromatic herbs in the industries such as the cosmetics, foods, hygienic products and perfumery (Lawrence, 1992). The secondary metabolites studied so far in this family are basically

\footnotetext{
* Author for correspondence: fagosti1@ucs.br
} 
terpenoids and flavonoids (Cole, 1992), although alkaloids, iridoids and ursolic acid have been found (Watson and Dallwitz, 1991). Many of the medicinal uses are presumed to be connected to the terpenic constituents of the essential oils of these plants (Richardson, 1992). Terpenoids are also linked to the chemical defenses of these plants against the attack of herbivores and pathogenic microorganisms (Cole, 1992). Some species of the family belonging to the genus Ocimum, Cunila, Mentha and Glechon are found spontaneously in the South of Brazil. The genus Ocimum is comprising more than 30 species of the herbs and shrubs from the tropical and subtropical regions of Asia, Africa and Central and South America, and is source of the essential oils which are used in pharmaceutical, perfume and cosmetical industry (Almeida et al., 2004). The genus Cunila is widely distributed throughout the America (Fracaro and Echeverrigaray, 2001) and consists of 22 species with two centers of distribution: Mexico with ten species and the southern part of South America with 12 species (Agostini et al., 2006). The essential oil composition of single species of the genus shows a large variation. Most of the species have a high content menthofuran, pulegone or citral (Fracaro and Echeverrigaray, 2001). Mints are herbaceous and perennial aromatic plants that are cultivated for their essential oils used for the medicinal and culinary purposes as well. These plants belong to the genus Mentha, which is native of the northern temperate regions and occurs in all the five continents (Gobert et al., 2002). There are about nine species of the genus Glechon, distributed from the southern Brazil to the northeastern Argentina and also in the southern Paraguay and Uruguay (Xifreda and Mallo, 2004). Leonurus is a widespread genus of the family Lamiaceae, which is represented by more than 20 species of the world flora (Tasdemir et al., 1995). Some species of the Lamiaceae family which are already exploited commercially, are exotic species from the Mediterranean, such as Ocimum basilicum, Origanum vulgare, Thymus vulgaris (Bozin et al., 2006), Rosmarinus officinalis (Angelini et al., 2003), Mentha piperita (Gobert et al., 2002), and others. The purpose of the present study was to perform a preliminary, informative study on the potential of a few Lamiaceae species in Rio Grande do Sul.

\section{MATERIAL AND METHODS}

\section{Collection}

Seven Lamiaceae species were collected from the different localities of Rio Grande do Sul. The species were classified and voucher specimens were deposited in the Museu de Ciências Naturais da Universidade de Caxias do Sul Herbarium. Table 1 presents the description of the collection.

Table 1 - Description of the collected Lamiaceae.

\begin{tabular}{lllcc}
\hline Sample & Species & Locality of collection & Collection date & Herbarium N \\
\hline 1 & Glechon Marifolia & Caçapava do Sul & $21 / 10 / 01$ & HUCS-19683 \\
2 & Glechon discolor & Vacaria & $27 / 10 / 01$ & HUCS-19691 \\
3 & Cunila incisa & Caxias do Sul & $24 / 10 / 01$ & HUCS-19691 \\
4 & Cunila microcephala & Caçapava do Sul & $21 / 10 / 01$ & HUCS-19684 \\
5 & Mentha aquática & Camaquã & $22 / 09 / 02$ & HUCS-20189 \\
6 & Ocimum selloi & São Francisco de Paula & $14 / 11 / 02$ & HUCS-20732 \\
7 & Leonurus sibiricus & Caxias do Sul & $26 / 09 / 02$ & HUCS-20333 \\
\hline
\end{tabular}

\section{Plant Material}

Samples of approx. $500 \mathrm{~g}$ of fresh plant material were used for the essential oil extractions. The material was subsequently dried under forced air circulation at $30^{\circ} \mathrm{C}$ for four days.

\section{Oil extraction}

The oils were isolated from the dried leaves by the hydrodistillation ( $1 \mathrm{~h})$ using a modified Clevengertype apparatus (Mechkovski and Akerele, 1992).
The isolated oils were dried over the anhydrous sodium sulfate (Merck, Germany). The samples were stored in a refrigerator $\left(+6^{\circ} \mathrm{C}\right)$ until Gas Chromatography (GC) and Gas Chromatography / Mass Spectrometry (GC/MS) analysis.

\section{Chemical Identification}

The GC analysis was performed with a Hewlett Packard 6890 Series equipped with a HPChemstation data processor, fitted with an HP- 
Innowax bonded phase capillary column (30 $\mathrm{m} \mathrm{x}$ $0.32 \mathrm{~mm}$ i.d.), $0.50 \mu \mathrm{m}$ film thickness (Hewlett Packard, Palo Alto, USA); column temperature, $40^{\circ} \mathrm{C}(8 \mathrm{~min})$ to $180^{\circ} \mathrm{C}$ at $3^{\circ} \mathrm{C} / \mathrm{min}, 180^{\circ}-230^{\circ} \mathrm{C}$ at $20^{\circ} \mathrm{C} / \mathrm{min}, 230^{\circ} \mathrm{C}(20 \mathrm{~min})$; injector temperature $250^{\circ} \mathrm{C}$; detector temperature $250^{\circ} \mathrm{C}$; split ratio 1:50; carrier gas $\mathrm{H} 2$ (34KPa). The volume injected was $1 \mu \mathrm{L}$ diluted in hexane $(1: 10)$.

The GC/MS analysis was performed with a HP 6890 GC using a Hewlett Packard 6890/MSD5973 mass selective detector, equipped with HP Chemstation software and Wiley 275 spectra data. An HP-Innowax fused silica capillary column (30 $\mathrm{m} \times 0.25 \mathrm{~mm}$ ), $0.25 \mu \mathrm{m}$ film thickness (Hewlett Packard, Palo Alto, USA) was used. The temperature program was the same used in the GC analysis: interface $280^{\circ} \mathrm{C}$; split ratio 1:100; carrier gas $\mathrm{He}(56 \mathrm{KPa})$; flow rate: $1.0 \mathrm{~mL} / \mathrm{min}$; ionization energy $70 \mathrm{eV}$; mass range 40-350; volume injected $0,4 \mu \mathrm{L}$ diluted in hexane $(1: 10)$. The components were identified by a combination of the mass spectrum of the Wiley library and the Kovats retention index, using a standard solution of hydrocarbons C9 to C26, and also by comparison with data from the literature. (Adams, 1995).

\section{RESULTS AND DISCUSSION}

About 30 components of the essential oils analyzed were identified and quantified, most of them commonly found in essential oils (Table 2). Each particular species had a distinct major chemical composition. C. incisa presented 1,8cineole $(45.17 \%)$, C. microcephala presented menthofuran $(52.71 \%)$, M. aquatica presented menthone $(77.76 \%)$ and $O$. selloi presented methyleugenol (35.68\%). Less known species such as $L$. sibiricus and $G$. discolor presented $\alpha$-pinene $(25.40 \%)$ and $\beta$-caryophyllene (25.03\%), respectively. The main component in G. marifolia could not be identified by The GC/MS and RI, and will be the basis of further investigation.

Considering the samples as a whole, sabinene was the only compound that was present in all collected species. Other important observations were performed on species of a same genus, as in the case of Glechon and Cunila. Broad differences in the qualitative and quantitative compositions were observed. For example 1,8-cineole was present in G. marifolia, or the high concentrations of $\beta$-caryophyllene $(25.03 \%), \quad \alpha$-humulene $(17.52 \%)$ and bicyclogermacrene $(13.16 \%)$ in $G$. discolor compared with those present in $G$. Marifolia essential oil.

Members of the genus Cunila had the same composition with 1,8 -cineole $(45.17 \%)$ and $\alpha$ terpineol $(17.93 \%)$ which were present only in $C$. incisa, and menthofuran $(52.71 \%)$ in $C$. microcephala. $C$. incisa had a similar composition to that observed for the populations evaluated in the study developed by Agostini et al. (2006). 1,8cineole, is used as bactericidal and stimulant (Duke, 1994; Serafini et al., 2001), and also in some cosmetics (Fenaroli, 1968), and $\alpha$-terpineol is used in the soaps, cosmetics and perfumery (Guenther, 1975). The study developed by Bordignon et al., (1997) shows a similar chemical composition for $C$.

microcephala, with a small variation in the content of the major compound, ranging from $82.3 \%$ to $85.1 \%$. Menthofuran shows the hepatotoxic properties (Bordignon et al., 1997), but it is mainly used in the perfume industry (Lawrence, 1992).

The chemical composition of $M$. aquatica oil showed a $77.76 \%$ menthone concentration and $14.39 \%$ pulegone, which can also be converted to menthol (Guenther, 1975). In the study by Jerkovic and Mastelic (2001), M. aquatica from southern Croatia presented menthofuran as its main compound, followed by 1,8-cineole and trans-caryophyllene. It is known that the environmental factors represented by altitude, temperature, luminosity, soil, animal-plant interactions, besides anthropic factors, may result in variations in the plant metabolic pathways (Mello and Silva-Filho, 2002) so that one often finds a variation of the chemical compounds present in the essential oils extracted from the plants of different origins. 
Table 2- Chemical composition of the volatile fraction of collected Lamiaceae.

\begin{tabular}{|c|c|c|c|c|c|c|c|c|c|}
\hline \multirow[t]{2}{*}{ Compound } & \multirow{2}{*}{$\begin{array}{l}\text { R.T. } \\
\text { (min.) }\end{array}$} & \multicolumn{7}{|c|}{ Area (\%) } & \multirow[t]{2}{*}{ R.I. } \\
\hline & & 1 & 2 & 3 & 4 & 5 & 6 & 7 & \\
\hline$\alpha$-pinene & 4.33 & 1.74 & - & 3.95 & 0.24 & - & - & 25.40 & 1011 \\
\hline$\alpha$-tujene & 4.52 & 1.34 & - & 1.31 & - & 0.87 & - & 0.88 & 1017 \\
\hline$\beta$-pinene & 7.57 & 0.76 & - & 1.25 & - & - & - & - & 1070 \\
\hline Sabinene & 8.45 & 1.94 & 0.25 & 4.17 & 0.23 & 0.90 & 0.79 & 2.53 & 1080 \\
\hline Myrcene & 11.21 & 2.64 & 0.60 & 1.17 & 0.14 & - & - & - & 1150 \\
\hline$\alpha$-terpinene & 11.64 & 0.72 & - & 0.89 & - & - & - & 4.71 & 1171 \\
\hline Limonene & 12.66 & 0.08 & 0.28 & 1.10 & 1.99 & - & - & - & 1201 \\
\hline 1,8-cineole & 13.02 & 11.72 & - & 45.17 & 3.05 & 1.49 & - & 1.60 & 1202 \\
\hline$\beta$-felandrene & 13.64 & 0.12 & - & 0.06 & - & - & - & 1.23 & 1206 \\
\hline$\gamma$-terpinene & 15.21 & 4.83 & - & 2.67 & - & - & 0.91 & 0.70 & 1241 \\
\hline trans- $\beta$-ocimene & 15.81 & 3.80 & 0.46 & 0.86 & - & - & 11.22 & - & 1243 \\
\hline Menthone & 25.35 & 0.58 & 0.09 & - & 0.08 & 77.76 & - & - & 1478 \\
\hline Menthofuran & 26.01 & - & - & - & 52.71 & - & - & - & 1503 \\
\hline Camphor & 26.95 & 2.09 & - & 0.07 & 0.17 & - & - & - & 1518 \\
\hline Linalool & 29.08 & 0.90 & 0.17 & 1.53 & 6.04 & 2.01 & - & - & 1526 \\
\hline Bornyl acetate & 30.24 & 4.39 & - & 0.12 & 4.72 & 0.35 & - & - & 1529 \\
\hline$\beta$-caryophyllene & 30.62 & 1.41 & 25.03 & - & - & 0.87 & 1.60 & 19.01 & 1547 \\
\hline$\beta$-bourbonene & 30.72 & - & 0.06 & - & - & - & 3.81 & - & 1550 \\
\hline terpinen-4-ol & 30.83 & 0.89 & 0.19 & 3.81 & 0.36 & - & - & - & 1553 \\
\hline Pulegone & 32.52 & - & - & - & - & 14.39 & - & - & 1555 \\
\hline$\alpha$-humulene & 32.96 & 0.68 & 17.52 & 0.06 & - & - & - & - & 1557 \\
\hline$\beta$-selinene & 33.33 & 0.06 & - & 0.36 & - & - & - & 11.19 & 1558 \\
\hline Germacrene-D & 34.45 & 3.47 & 7.98 & - & 4.18 & - & 14.26 & 8.96 & 1599 \\
\hline$\alpha$-terpineol & 34.48 & - & - & 17.93 & - & - & - & - & 1600 \\
\hline Bicyclogermacrene & 35.38 & 4.46 & 13.16 & 0.18 & 1.58 & 0.19 & - & - & 1652 \\
\hline$\beta$-elemene & 36.35 & 1.93 & 4.21 & 0.10 & 0.54 & - & - & - & 1716 \\
\hline Farnesene & 36.79 & - & - & - & - & - & 8.48 & - & 1756 \\
\hline Unknown & 41.58 & 13.87 & - & - & 1.70 & 0.14 & - & - & 1917 \\
\hline Methyleugenol & 45.55 & - & 0.10 & - & - & - & 35.68 & 0.75 & 1965 \\
\hline Spathulenol & 48.24 & 1.80 & 3.08 & 0.14 & 0.84 & - & - & 0.73 & 2025 \\
\hline Thymol & 50.45 & 4.42 & - & - & 0.44 & - & - & - & 2081 \\
\hline
\end{tabular}

Species: 1-Glechon marifolia, 2-Glechon discolor, 3-Cunila incisa, 4-Cunila microcephala, 5-Mentha aquatica, 6-Ocimum selloi, 7-Leonurus sibiricus - R.T. : Retention Time - R.I.: Kovats Retention Indice

As for M. aquatica, the essential oil of $O$. selloi also showed the variations in its chemical composition depending on site and date of the collection, according to data from the literature. O. selloi presented $35.68 \%$ methyleugenol in the sample studied. Moreover, according to Martins et al., (1997), the samples collected in Minas Gerais presented different major compounds. In access A, the major compound was estragol $(94.95 \%)$ and in access $\mathrm{B}$, it was methyleugenol (65.48\%). Moraes et al., (2002) cites trans-anetol (41.34\%) and methyl-chavicol $(24.14 \%)$ as the major constituents of the essential oil of the $O$. selloi. Table 3 presents the essential oil yield for the collected samples, ranging from $0.10 \%(\mathrm{v} / \mathrm{w})$ in $L$. sibiricus to $1.94 \%(\mathrm{v} / \mathrm{w})$ in C. incisa. C. incisa has the best essential oil yield, superior to that presented by Agostini et al., (2006) which varied from $1 \%$ to $1.3 \%$. M. aquatica has a $0.93 \%(\mathrm{v} / \mathrm{w})$ oil yield, in agreement to Jerkovic and Mastelic (2001) who found the oil content of $0.94 \%$ in $M$. aquatica. O. selloi presented an oil content of $0.34 \%$ and was higher to that described by Moraes et al., (2002) which varied from 0.20 to $0.25 \%$. 
Table 3 - Essential oil yields (\%v/w).

\begin{tabular}{cc}
\hline Species & Essential oil yield (\%)/w) \\
\hline Glechon Marifolia & 0.30 \\
Glechon discolor & 0.50 \\
Cunila incisa & 1.94 \\
Cunila microcephala & 0.26 \\
Mentha aquatica & 0.93 \\
Ocimum selloi & 0.34 \\
Leonurus sibiricus & 0.10 \\
\hline
\end{tabular}

Despite other factors that alter the yields and chemical compositions of the essential oils, such as the environmental conditions, period of collection, growth phase of the plants, genetic variability and others (Price and Price, 1999; Simões and Spitzer, 2000). The identification of plants to the region that are potentially useful encourages the extensive study of native flora. The biodiversity of the native flora of Rio Grande do Sul still includes many plants which have not been studied much, and can result in new products for the perfume, cosmetical and aroma industries.

\section{ACKNOWLEDGEMENTS}

The authors wish to acknowledge the contributions of Coordenação de Aperfeiçoamento de Pessoal de Nível Superior / Conselho Nacional de Pesquisa (CAPES/CNPq), Universidade de Caxias do Sul (UCS) and the Secretaria de Ciência e Tecnologia do Estado do Rio Grande do Sul (SCT-RS).

\section{RESUMO}

Em vista do reconhecimento de espécies da família Lamiaceae como produtoras de óleos essenciais, este trabalho teve como objetivo identificar algumas espécies nativas do Rio Grande do Sul, bem como avaliar seu potencial aromático. Para isso, foram coletadas sete amostras pertencentes à esta família, em diferentes localidades do Estado. $\mathrm{O}$ óleo essencial foi obtido por hidrodestilação em aparelho Clevenger pelo período de 1 hora. Os compostos foram identificados por comparação de seus Índices de Retenção de Kovats (R.I), deterninados com referência a uma série homóloga de $n$-alcanos e por comparação de seus padrões de fragmentação de massa com dados da literatura. $C$. incisa e M. aquatica, apresentaram os melhores rendimentos de óleo essencial (1.94\% v/p e $0.93 \%$ v/p respectivamente). M. aquatica também destacou-se por apresentar cerca de $80 \%$ de mentona, além de pouco mais de $14 \%$ de pulegona. C. microcephala apresentou aproximadamente $53 \%$ de mentofurano e $C$. incisa cerca de $45 \%$ de 1,8 -cineol e $18 \%$ de $\alpha$-terpineol.

\section{REFERENCES}

Adams, R. P. (1995), Identification of essential oils by ion mass spectroscopy. Academic Press, Inc, California.

Agostini, G.; Agostini, F.; Serafini, L. A.; Echeverrigaray, S. (2006), Essential oil variability within and among populations of Cunila incisa Benth. Biochemical Systematics and Ecology, 34, 802-808.

Almeida, C. F. C. B. R.; Albuquerque, U. P. (2002), Check-list of the family Lamiaceae in Pernambuco, Brazil. Brazilian Archives of Biology and Technology, 45 (3), 343-353.

Almeida, O. S.; Silva, A. H. B.; Silva, A. B.; Silva, A. B.; Amaral, C. L. F. (2004), Estudo da biologia floral e mecanismos reprodutivos do alfavacão (Ocimum officinalis L.) visando o melhoramento genético. Acta Scientiarum. Biological Sciences, 26 (3), 343-348.

Angelini, L. G.; Carpanese, G.; Cioni, P. L.; Morelli, I., Macchia, M.; Flamini, G. (2003), Essential oils from Mediterrenean Lamiaceae as weed germination inhibitors. J. Agric. Food Chem., 51 (21), 6158-6164.

Bordignon, S.A.; Schenkel, E.P.; Spitzer, V. (1997), The essential oil composition of Cunila microcephala and Cunila fasciculata. Phytochemistry, 44 (7), 12831286.

Bozin, B.; Mimica-Dukic, N.; Simin, N.; Anackov, G. (2006), Characterization of the volatile composition of essential oils of some Lamiaceae spices and the antimicrobial and antioxidant activities of the entire oils. J. Agric. Food Chem., 54 (5), 1822-1828.

Cantino, P. D. (1992), Evidence for a polyphyletic origin of Labiatae. Ann. Missouri Bot. Gard., 79, 361379.

Cole, M. D. (1992), The significance of the terpenoids in the Labiate. In-Advances in Labiate Science, ed. 
Royal Botânic Gardens KEW, Whitstable, pp 315324.

Craveiro, A. A.; Fernandes, A. G.; Andrade, C. H. S.; Matos, F. J. D. A.; Alencar, J. W. D.; Machado, M. I. L. (1981), Óleos Essenciais de Plantas do Nordeste. UFC, Fortaleza.

Duke, J. A. (1994), Spices, Herbs and Edible Fungi. Elsevier, New York.

Fenaroli, G. (1968), Sostanze Aromatiche Isolate $e$ Sintetiche. Tomo I e II . Hoepli, Italy.

Fracaro, F.; Echeverrigaray, S. (2001), Micropropagation of Cunila galioides, as popular medicinal plant of south Brazil. Plant Cell, Tissue and Organ Culture, 64, 1-4.

Gobert, V.; Moja, S.; Colson, M.; Taberlet, P. (2002), Hybridization in the section Mentha (Lamiaceae) inferred from AFLP markers. American Journal of Botany, 89 (12), 2017-2023.

Guenther, E. (1975) The Essential Oils: The Contituents of Essential Oils. Vol. II. Krieger, Florida.

Jerkovic, I.; Mastelic, J. (2001), Composition of free and glycosidically bound volatiles of Mentha aquatica L.. Croatica Chemica Acta, 74 (2), 431-439.

Lawrence, B. M. (1992), Chemical components of Labiate oils and their explotation. In-Advances in Labiate Science, ed. Royal Botânic Gardens KEW, Whitstable, pp. 399-436.

Martins, E. R.; Casali, V. W. D.; Barbosa, L. C. A.; Carazza, F. (1997), Essential oil in the taxonomy of Ocimum selloi Benth. Journal of Brazilian Chemistry Society, 8, 29-32.

Mechkovski, A.; Akerele, C. O. (1992), Quality control methods for medicinal plant materials. Who/Pharm/92.559. Switzerland: World Health Organization.

Mello, O. M.; Silva-Filho M. C. (2002). Plant-insect interactions: an evolutionary arms race between two distinct defense mechanisms. Brazilian Journal Plant Physiology, 14, 71-81.
Moraes, L. A. S.; Facanali, R., Marques; M. O. M., Ming; L. C., Meireles, M. A. A. (2002), Phytochemical characterization of essential oil from Ocimum selloi Benth. An. Academia Brasileira de Ciência, 74 (1), 183-186.

Price, S.; Price, L. (1999), Aromaterapy for Health Professionals. $2^{\text {nd }}$ edition. Churchill Livingstone, New York.

Richardson, P. M. (1992), The chemistri of the Labiate: An introduction and overview. In-Advances in Labiate Science, ed. Royal Botanic Gardens KEW, Whitstable, pp. 291-297.

Serafini, L. A.; Barros, N. M. D; Azevedo, J. L. D. (2001), Biotecnologia: Princípios e Aplicações. InBiotecnologia na Agricultura e na Agroindústria, ed. Agropecuária, São Paulo, pp. 25-69.

Simões, C.M.O.; Spitzer, V. (2000), Óleos Voláteis. InFarmacognosia, ed. Universidade Federal do Rio Grande do Sul, Porto Alegre, pp. 387-415.

Tasdemir, D.; Wright, A. D.; Sticher, O. (1995), Detailed ${ }^{1} \mathrm{H}$ and ${ }^{13} \mathrm{C}-\mathrm{NMR}$ investigations of some diterpenes isolated from Leonurus persicus. Journal of Natual Products, 58 (10), 1543-1554.

Watson, L.; Dallwitz, M.J. (1991), The families of angiosperms: automated descriptions, with interactive identification and information retrieval. Aust. Syst. Bot., 4, 681-95.

Xifreda, C. C.; Mallo, A. C. (2004), Las especies Argentinas de Glechon (Lamiaceae, Mentheae). Darwiniana, 42 (1-4), 333-346.
Received: June 09, 2006; Revised: February 27, 2007; Accepted: June 02, 2008. 